Proc. Estonian Acad. Sci. Eng., 2004, 10, 1, 10-17

\title{
Melting and modification by producing ductile iron castings
}

\author{
Stasys Bočkus ${ }^{\mathrm{a}}$ and Aloyzas Dobrovolskis ${ }^{\mathrm{b}}$ \\ a Department of Metal Technology, Kaunas University of Technology, Kestucio St. 27, 3004 \\ Kaunas, Lithuania; stasys.bockus@ktu.lt \\ b Joint-Stock Company "Kauno Ketaus Liejykla", R. Kalantos St. 46, 3014 Kaunas, Lithuania; \\ ketus@takas.lt
}

Received 1 September 2003, in revised form 3 November 2003

\begin{abstract}
The effect of charge materials, melting conditions, section size, spheroidizing and inoculation methods on the chemical composition of melt and the matrix microstructure of ductile iron castings has been investigated. Results show that the amount of pig iron in the charge and the section size have a significant effect on the amount of ferrite in ductile iron castings. The increase of the temperature and holding duration of the melt in an induction furnace decreases the carbon content and increases the silicon content. The intensity of spheroidizing affects the carbon and residual magnesium contents in the ductile iron castings.
\end{abstract}

Key words: ductile iron, charge, spheroidizing, inoculation, metallic matrix.

\section{INTRODUCTION}

Ductile iron with high strength and toughness has been available as an engineering material for many years, replacing forging steel, cast steel, and malleable cast-iron. It has undergone a phenomenal development and has become the only ferrous casting material with positive growth rate. The ductile iron will still be an important construction material in the 21 st century [ $\left.{ }^{1,2}\right]$.

Ductile iron is a ternary $\mathrm{Fe}-\mathrm{C}-\mathrm{Si}$ alloy, in which the concentrations of carbon and silicon vary typically from 3.5 to $3.9 \%$ and from 1.8 to $2.8 \%$, respectively. The selection of the composition is dictated by the casting section size and by the targeted mechanical properties. The output characteristics depend on the matrix structure and the shape, size, and distribution of the graphite spheroids. Matrix and spheroids, in their turn, depend on the chemical composition of the melt, on the desulphurizing and spheroidizing methods applied in the treatment ladle, on 
the inoculation method and finally, on the time elapsing between these events and the casting in the mould $\left[{ }^{3}\right]$. Moreover, the mechanics of spheroid formation itself has not yet been completely understood and many models are still in competition $[4,5]$.

Production of ductile iron is influenced by a large number of metallurgical, technological, heat transfer, and designing parameters. The first step of the production of ductile iron castings is careful selection of the charge materials.

Manganese and chromium have the most strong influence on mechanical properties of the ductile iron $\left[{ }^{6}\right]$. For this reason, their concentration in the metal is of particular importance. These elements arise in the charge from the steel scrap, pig iron, and returns. It is a recommended practice to surchage steel scrap so that the average $\mathrm{Cr}$ content remains below 0.1 percent. Ideally, the same advice would be given for Mn but, unfortunately, all steel scraps contain Mn, mostly about 0.5 percent. The amount of steel scrap in the charge must ensure the production of castings that are as free of carbides as possible [ $\left.{ }^{7}\right]$.

It is necessary not to mix grey iron return scrap with the ductile iron one, because grey iron castings have an increased manganese and chromium content. Ductile iron return scrap has a large silicon and a small sulphur content. However, if spheroidizing elements are present in excessive concentration they act as despheroidizers $\left[{ }^{8}\right]$.

Charge materials result in the average size of graphite spheroids. For instance, if the amount of the steel scrap in the charge is more than 50 percent then an average spheroid diameter is $33 \mu \mathrm{m}$, if it is 30 percent then the average diameter is $57 \mu \mathrm{m}\left[{ }^{9}\right]$. The amount of the steel scrap affects the metallic matrix structure as well, increasing the pearlite formation. However, fully pearlitic castings are produced more easily by adding copper $\left[{ }^{10}\right]$.

The graphite structure is also affected by the carbon content. If the initial metal does not contain enough carbon then graphite particles have a compact form $\left[{ }^{11}\right]$. The metallic matrix structure is affected not only by carbon equivalent but also by the $\mathrm{C} / \mathrm{Si}$ ratio. Increasing this ratio in ductile iron decreases the proportion of ferrite and increases the proportion of pearlite $\left[{ }^{12}\right]$.

The formation of graphite spheroids is obtained through a special treatment, during which spheroidizing elements are added to the melt. Both $\mathrm{Mg}$ and various $\mathrm{Mg}$ alloys are most commonly used for ductile iron spheroidization $\left[{ }^{13}\right]$. The choice of a treatment method (open ladle, sandwich, tundish cover, in-mould, plunger, converter, injection, and others $\left[{ }^{14}\right]$ ) for an individual foundry must be based on the circumstances present in the foundry.

Inoculation, which may take place at different phases of the process, is a necessary step in the production of ductile iron castings. Most inoculants are ferrosilicons. An inoculant grade $\mathrm{FeSi}$ always contains elements in relatively low concentration, which are active inoculants, such as $\mathrm{Ca}, \mathrm{Al}, \mathrm{Zr}, \mathrm{Ba}, \mathrm{Sr}$, and $\mathrm{Ti}\left[{ }^{15}\right]$. These elements are used to increase the solubility of the alloys. There are three ways to inoculate the metal, which are used individually or in combination $\left[{ }^{16}\right]$ : in the ladle, in the stream while pouring or reladling, and in the mould. 
This very brief survey shows that, although considered as a mature technology, recent process and product developments open new avenues to this family of materials. In this study, efforts have been focused on the charge materials, melting, and modification aspects of producing ductile iron castings. The objective of this work is to study the change in chemical composition of the melt with its temperature, holding time in the furnace and spheroidizing intensity, and also clarify the effect of charge composition and section size on the matrix microstructure.

\section{MATERIALS AND EXPERIMENTAL PROCEDURES}

\subsection{Charge materials}

The charge materials, used for the production, are listed in Table 1. They are melted in the standard line frequency induction furnace.

\subsection{Spheroidizing}

Spheroidizing was carried out in a special ladle $\left[{ }^{17}\right]$ by means of the sandwich method at about $1500^{\circ} \mathrm{C}$. The treatment ladle was preheated to avoid temperature losses. Spheroidizing was performed by means of $2.1 \%$ of FeSiMg7. After spheroidizing, the top of the ladle was lifted and the melt was delagged and poured into the casting ladle.

We investigated the influence of the time of spheroidizing in the ladle on the graphite content in the liquid ductile iron. Three kinds of spheroidizing processes have been studied: very fast (with evaporation and burning of the magnesium, $4 \mathrm{~s})$, medium (15 s), and very slow (100 s).

\subsection{Inoculation}

The metal stream, ladle, and in-mould inoculation methods were applied to obtain different nodularity and metallic matrix structure.

Inoculation was performed by means of $0.40 \%$ of $\mathrm{FeSi}-\mathrm{Ba}(60-65 \% \mathrm{Si}, 2 \% \mathrm{Ca}$, $5-6 \% \mathrm{Ba})$. After inoculation the temperature was measured and part of the melt was poured into the chill mould for spectrographic analysis of the ductile iron pro-

Table 1. Details of the charge materials

\begin{tabular}{l|c|c}
\hline \multirow{2}{*}{ Charge materials } & \multicolumn{2}{c}{ Percentage for ductile iron } \\
\cline { 2 - 3 } & Experimental & Basic \\
\hline Pig iron & $10-70$ & 50 \\
Mild steel & $30-50$ & 20 \\
Return scrap & $30-60$ & 26 \\
FeSi75 & $1-3$ & 1.5 \\
Carburizing agent & $2-3$ & 2.5
\end{tabular}


duced. During in-mould inoculation the inoculant $(0.1-0.2 \%$ of FeSi-Ba) was placed in a reaction chamber within the gating system of the individual mould.

\subsection{Testing}

All castings were produced in green sand moulds. Standard test pieces for the testing of the microstructural and mechanical properties were prepared from the samples cast separately in sand moulds under spheroidization and inoculation. Test pieces were prepared in accordance with LST EN1563:2001. The microstructure was examined by optical microscopy. The part of the melt was poured into the cool mould for the spectrographic analysis of the produced ductile iron.

Effect of the section size on the metallographic structure was investigated with $6-30 \mathrm{~mm}$ thick sections. During the tests only the metallic matrix was examined because it is known $\left[{ }^{7}\right]$ that graphite spheroids are larger and usually not so well formed in heavy sections than in the thin ones.

\section{RESULTS AND ANALYSIS}

\subsection{The change in chemical composition of the melt}

The initial chemical composition of the melt depends on its temperature and holding time in the furnace. Figure 1 shows that the carbon content of the melt decreases from 3.90 to 3.65 percent (at $1480^{\circ} \mathrm{C}$ ) or to 3.53 percent (at $1580^{\circ} \mathrm{C}$ ) during holding in the furnace for $3 \mathrm{~h}$. Litovka et al. $\left[^{8}\right]$ have also observed that the effectiveness of the spheroidizing process decreases with increasing holding time of melt in the furnace but the effectiveness of spheroidizing process is lower in case of cast iron containing less carbon $\left[{ }^{11}\right]$. However, silicon content at the same time increases from 1.47 to 1.70 percent (Fig. 2). That is why it is necessary to control the chemical composition of the melt in the furnace and to regulate it. Therefore the inoculation is introduced in the furnace and in the ladle before spheroidizing.

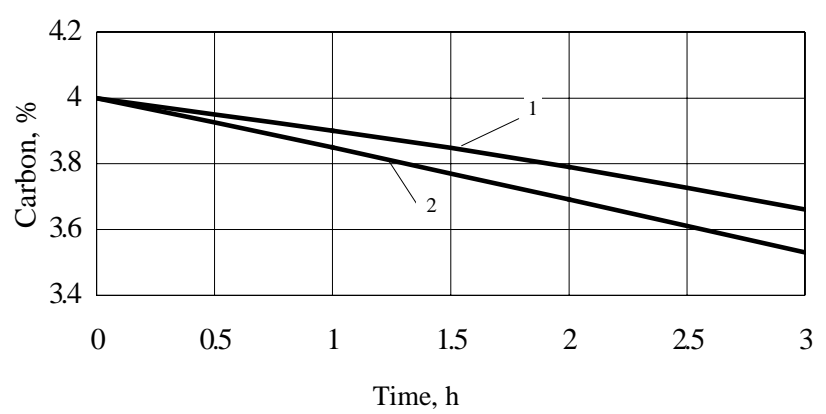

Fig. 1. Change of the carbon content of the melt held in a furnace: $1-$ at $1480^{\circ} \mathrm{C} ; 2-$ at $1580^{\circ} \mathrm{C}$. 




Fig. 2. Change of the silicon content of the melt held in a furnace at $1580^{\circ} \mathrm{C}$.

Carbon content depends also on the intensity of the spheroidizing as shown in Fig. 3. It is evident that the carbon content decreases with the increase of the spheroidizing time.

Figure 4 shows that the spheroidizing intensity affects also the residual magnesium content. As may be seen, the residual magnesium content is the highest when the spheroidizing time is about $15 \mathrm{~s}$.

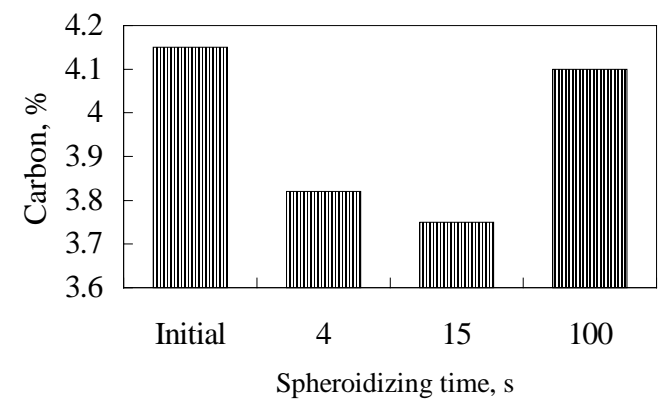

Fig. 3. Effect of spheroidizing time on the carbon content.

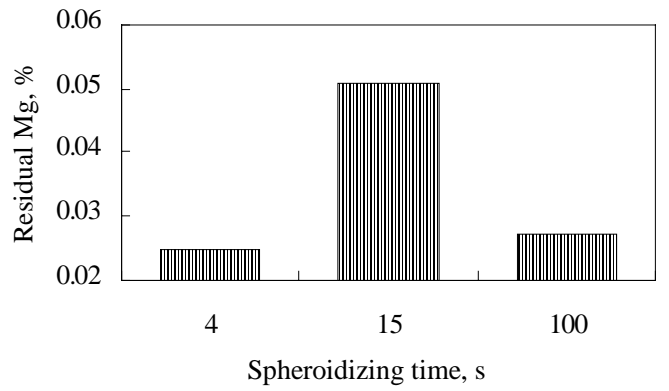

Fig. 4. Effect of spheroidizing time on the content of residual magnesium. 


\subsection{Effect of charge composition and section size on the matrix microstructure}

Figure 5 shows the relationship between the amount of pig iron in the charge and the mechanical properties (tensile strength and elongation). It is evident that ferritic ductile iron requires larger amount of pig iron. Kapilevich et al. $\left[{ }^{18}\right]$ have observed the same tendency. They reported that the amount of pig iron in the charge of ferritic ductile iron grade 400 as cast must be higher than 53 percent as in the present work. But there are some differences between our results at other grades. They recommended 34.5 percent of pig iron for the grade 500 and 31 percent for the grade 600 while we did not get stable results with these amounts of pig iron.

The amount of the ferrite in sections of different thickness is shown in Fig. 6. It shows that it is very difficult to pour a thin section of ferrite ductile iron ascast. It is associated with high solidification rate and formation of carbides.

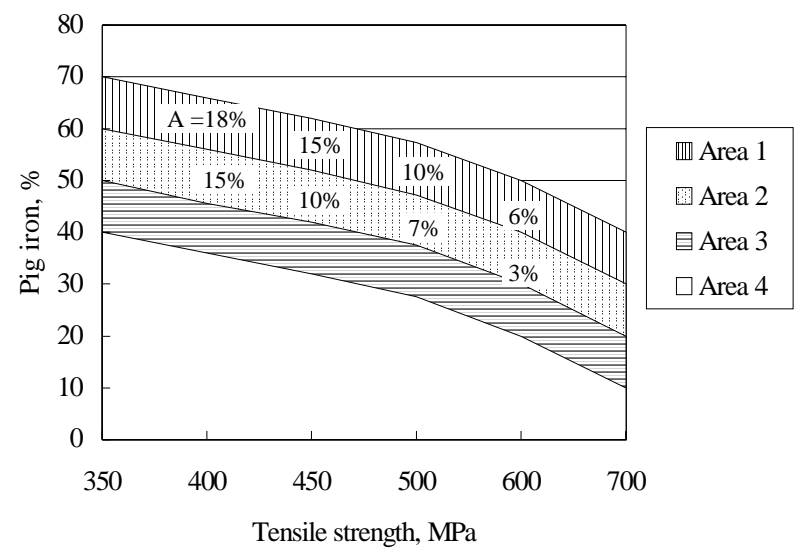

Fig. 5. Recommended amount of pig iron in the charge for different ductile iron grades (tensile strength and elongation A); areas 1 and 2 represent the stable process.



Fig. 6. Effect of the section thickness on the content of ferrite. 
Thin castings of ductile iron will be ferritic as-cast only when optimum chemical composition, short melt holding in the furnace, large amount of pig iron in the charge, high purity charge materials, and a special treatment of the melt are used. The results of industrial experiments show that the most effective treatment technique of the melt for pouring 6-12 mm thick sections consists of four steps: inoculation in the transfer ladle, spheroidizing in the treatment ladle, inoculation in the stream while pouring, and inoculation in the mould. On the basis of the research results, ductile iron castings with $5-10 \mathrm{~mm}$ wall thickness have been introduced into production.

\section{CONCLUSIONS}

1. It can be concluded that the initial chemical composition of the melt depends on its temperature and holding time in the induction furnace. High temperature and long holding time decrease carbon content but increase the content of silicon.

2. It is found that very intensive and very slow spheroidizing process decreases the content of carbon and residual magnesium in the ductile iron.

3. The present investigation has shown that the castings of ductile iron will be ferritic as-cast only when a large amount of pig iron is used in the charge. However, producing as-cast ferritic thin-section ductile iron castings needs in addition several steps of inoculating treatment.

\section{REFERENCES}

1. Fatahalla, N., Bahi, S., and Hussein, O. Metallurgical parameters, mechanical properties and machinability of ductile cast iron. J. Mater. Sci., 1996, 31, 5765-5772.

2. Liu, J. H., Hoo, X. Y., Li, G. L., and Liu, G. Sh. Microvoid evaluation of ferrite ductile iron under strain. Mater. Lett., 2002, 56, 748-755.

3. Beeley, P. Foundry Technology. Butterworth-Heinemann, Oxford, 2001.

4. Sytnik, N. M. Mechanism of crystallization of spheroidal graphite in cast iron. Met. Sci. Heat Treat., 1991, 33, 317-322.

5. Almansour, A., Kozuhiro, M., Hatayma, T., and Yanagisawa, O. Simulation solidification of spheroidal graphite cast iron of Fe-C-Si systems. Mater. Trans. JIM, 1995, 36, 1487-1495.

6. Chaykin, V. A. and Ishutin, V. V. Raising of mechanical properties of ductile iron. Lit'e $i$ Metallurgiya, 2002, No. 4, 71-75 (in Russian).

7. Karsay, S. J. Ductile Iron Production Practices. Am. Foundrym. Soc. Inc. Des Plaines, Illinois, 1994.

8. Litovka, V. I., Sheyko, A. A., and Zeliony, B. G. Technology for ductile iron production. Litejnoe Proizvodstvo, 1983, No. 4, 13-14 (in Russian).

9. Krestyanov, V. J. Some conditions for producing nodular iron with a high complex of as-cast mechanical properties. Litejnoe Proizvodstvo, 1991, No. 7, 2-5 (in Russian)..

10. Ovchinnikov, V. I., Tiutin, D. B., and Zvolinskij, A. S. Effect of copper on structure and properties of ductile iron. Litejnoe Proizvodstvo, 1992, No. 1, 10-11 (in Russian).

11. Shaprikov, I. A. Effect of carbon content on the ductile iron quality. Litejnoe Proizvodstvo, 1992, No. 11, 6-7 (in Russian).

12. Solntsev, L. A. et al. Influence of $\mathrm{C} / \mathrm{Si}$ ratio on kinetics of austenite transformation and structure of high-duty iron. Litejnoe Proizvodstvo, 1976, No. 6, 3-4 (in Russian). 
13. Shebatinov, M. P., Abromenko, Y. Y., and Bekh, N. I. Highly Strong Cast Iron in Car Industry. Mashinostroenie, Moscow, 1988 (in Russian).

14. Kornienko, E. N. Spheroidizing inoculants for nodular iron production. Litejnoe Proizvodstvo, 1998, No. 10, 24-26 (in Russian).

15. Torbjern, S. Retardation of inoculation process in cast iron with different graphite shape Litejnoe Proizvodstvo, 1999, No. 5, 11-13 (in Russian).

16. Zakharchenko, E. V., Levchenko, Y. N., Gorenko, V. G., and Varenik, P. A. Cast Iron with Spherical Graphite. Naukova Dumka, Kiev, 1986 (in Russian).

17. Bočkus, S. and Dobrovolskis, A. Feature of ductile iron producing technology. Mater. Sci. Medziagotyra, 2002, 8, 372-374.

18. Kapilevich, A. N., Aleksandrov, N. N., Jakovlev, M. I., and Kovalevich, Y. V. Some aspects of theory and production of ductile iron. Litejnoe Proizvodstvo, 2001, No. 3, 4-5 (in Russian).

\section{Sulatamine ja modifitseerimine kõrgtugevast malmist valandite tootmisel}

\section{Stasys Bočkus ja Aloyzas Dobrovolskis}

On uuritud lähtematerjalide, sulatustingimuste, malmi sferoidiseerimise ja modifitseerimise meetodite mõju kõrgtugevast malmist valandite keemilisele koostisele ja mikrostruktuurile. On näidatud, et kuumutustemperatuuri ja -aja kasv induktsioonahjudes vähendab malmi süsinikusisaldust, suurendab ränisisaldust ning mõjutab sferoidiseerimisprotsessi intensiivsust. 